\title{
Craniofacial variation of the Xiongnu Iron Age nomads of Mongolia reveals their possible origins and population history
}

Ryan W. Schmidt ${ }^{a, b}$, Noriko Seguchi, ${ }^{c}$

${ }^{\text {a }}$ Department of Anthropology

The University of Montana, Missoula

32 Campus Drive

Missoula, MT 59812 United States

Present Address:

${ }^{\mathrm{b}}$ Department of Anatomy

Kitasato University, School of Medicine

1-15-1 Kitasato, Minami-ku, Sagamihara-shi, Kanagawa

252-0374 Japan

tel: +81 042-778-9022

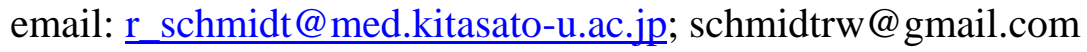

${ }^{\mathrm{c}}$ Department of Environmental Changes

Graduate School of Social and Cultural Studies

Kyushu University

744 Motooka, Nishi-Ku, Fukuoka City

Fukuoka, Japan 819-0395

email: noriko.seguchi@scs.kyushu-u.ac.jp

\section{Abstract}

This paper examines Iron Age Mongolia during a time when nomadic tribes created the world's first steppe empire in Inner Asia. These aggregated tribes, known as Xiongnu (3rd century $\mathrm{BC}$ to the 2nd century AD), came to define steppe polity construction, later used by the Mongol Empire under the reign of Genghis Khan. They moved extensively over the eastern steppe and interacted, both in trade and intermarriage, with peoples from southern Siberia to Xinjiang. However, the Xiongnu as a people are relatively unknown to scholars, as they did not possess a written language. This study assesses Xiongnu population history and biological structure by analyzing craniofacial diversity via geometric morphometrics. Twenty-four coordinate cranial landmarks were used to test relationships among groups in the region and infer potential biological origins. The Relethford-Blangero R-matrix method was used to test hypotheses of phenotypic variation resulting from microevolutionary processes. This study hypothesizes biological continuity among Xiongnu individuals extending into modern Mongolian populations. Alternatively, long-range gene flow from adjacent geographic regions might suggest a complex 
population structure among the Xiongnu indicative of multiple populations controlling administrative functions. Results indicate the Xiongnu were potentially composed of at least two biologically distinct groups. Individuals from the elite cemetery of Borkhan Tolgoi (Egiin Gol) share their ancestry with a Bronze Age population from western Mongolia, and possibly, to a later migration of Turks, who came to rule the eastern steppe from the 6th-8th centuries AD. The Xiongnu also evidence biological similarity with nomads from the Mongol Empire during the medieval period and modern Mongolians, as well as modern and ancient Central Asian, Chinese, and Siberian groups. These results are similar to ancient DNA studies that suggest a mix of Eastern and Western Eurasian haplogroups in the Xiongnu while also achieving consensus with models of steppe polity formation proposed by archaeologists who suggest local ties to extra-local groups through interactive exchange networks.

Keywords: geometric morphometrics; population structure; $R$ matrix; Inner Asia; Iron Age; quantitative genetics

\section{Introduction}

Genghis Khan (c. AD 1162 - AD 1227) founded the Mongol empire in AD 1206, in what would later become the largest contiguous land empire in known history (Morgan, 1986). Stretching from Eastern Europe to the Sea of Japan, the Mongols ruled and conquered a vast array of peoples. Though the Mongol empire was known for rapid territorial expansion with brutal conquering efficiency, they were not the first nomadic empire to rule from horseback. The Mongols are just one in a long succession of polities that ruled over the vast Inner Asian steppe beginning in the second century BC. Chinese historical records and more recent archaeological investigation indicate these small-scale societies aggregated into novel organizational forms as large-scale, hierarchically organized, integrated polities of pastoral peoples. This study concerns the first of those steppe polities, a group of nomads that resided in what is now central and northern Mongolia, though at their height, were known to control a large territory of Inner Asia. Chinese scholars referred to these Iron Age people as Xiongnu. However, the peoples of the Xiongnu were among several nomadic cultures to inhabit parts of greater Northern Asia throughout the Iron Age, including the Tagar and Pazyryk of Siberia and the Xianbei of Northeast China. Although these terms represent various aggregated tribes, peoples, and possibly 
ethnicities, Figure 1 uses names ascribed to archaeological cultures in order to present potential interaction spheres amongst these nomadic peoples.

As a confederation established at the end of the first millennium $\mathrm{BC}$ and disintegrated sometime during the $2 \mathrm{nd}$ or 3rd century $\mathrm{AD}$, there is still much that scholars do not understand about Xiongnu origins and its people. As a non-literate society, much information comes from sources written by Chinese historians during the Qin (BC 221 - BC 206) and Han Dynasties (BC 206 - AD 220). Though much of what we do know archaeologically and genetically come from a mortuary and burial context, very little research has been undertaken using skeletal quantitative traits in an effort to answer anthropologically important questions about origins, migration, and interactions with peoples in the greater Northern Eurasian region.

In addition, most researchers assume archaeological samples to be composed of biologically or ethnically homogenous individuals. Xiongnu as a single homogenous tribe can be contested using methods presented here and in combination with other studies using ancient genetic data. For example, Chinese accounts of the Xiongnu were often fluid and changed depending on the political dynamic at the time (Miller, 2009). In northeast China, some of the Hu groups became known as Xianbei, who it appears were subsumed under the label Xiongnu during the steppe polity's reign, but regained the label Xianbei after the collapse of the Xiongnu Empire. This example illustrates the nature of possible multiple ethnicities within the Xiongnu Empire as political or military circumstances changed.

The Xiongnu polity is the prototypical example of regional political organization on the northeastern steppe, defined as the territories of Mongolia, South Siberia, and Chinese Inner Mongolia (Allard and Erdenebaatar, 2005; Honeychurch and Amartuvshin, 2006; Houle, 2010). Archaeological evidence of the Xiongnu comes from Mongolia and the Zabaikal'e region located along the Selenge River valley to the shores of Lake Baikal in southern Siberia (Allard et al., 2002; Crubezy et al., 2006; Wright et al., 2009). Xiongnu material culture has been radiocarbon dated and a firm chronological framework established (Hall et al., 1999). This material culture includes evidence for a complex and large-scale polity of pastoral nomads. The burials reveal a hierarchy of scale and mortuary style and complexity. Large, royal tombs were immense constructions tens of meters square and deep (Wright, 2006). The most common grave associated with Xiongnu material culture are stone 
ring burials between five and ten meters in diameter with a central shaft two or more meters deep at the center, usually containing a wooden or stone coffin.

Xiongnu graves are normally found in groups, ranging in size from a few burials to hundreds of structures of various sizes. Within the core area of Xiongnu control (central Mongolia), three-level size hierarchies appear within the defined cemetery types (Honeychurch, 2003). The first are large cemeteries containing massive square tombs and hundreds of associated ring graves. The second rank cemeteries include the so-called 'hundred grave cemeteries' such as Borkhan Tolgoi in the Egiin Gol valley of northern Mongolia and Baga Gazarynn Chuluu located in the Middle Gobi. We include several individuals from Borkhan Tolgoi in this study. Surrounding these second level cemeteries are smaller, more localized cemeteries, with spatially distinct burial locales with less than a dozen graves. Wright et al. (2009) suggest a regional system of hierarchy and political organization as evidenced in the material remains of grave goods found in both smaller cemeteries and lager elite cemeteries.

These non-local connections seem to connect inhabitants of smaller settlement sites to a larger system of external decision-making. Grave goods, such as silks, jade items, bronze mirrors, and Chinese lacquer indicate a tribute system in payment by Chinese rulers to Xiongnu elite. However, the archaeological evidence points to a more complex and sophisticated exchange network. At the large elite cemetery of Noyon Uul, material and textual evidence suggest the Xiongnu elite also developed a system of exchange with Bactrian origins in Central Asia (Honeychurch and Amartuvshin, 2006). Ancient Bactria refers to individuals composed of the Oxus civilization who inhabited the Hindu Kush valley of northern Afghanistan. This archaeological evidence would suggest continued genetic exchange among peoples from China to Afghanistan with the elite Xiongnu nomads of Mongolia.

Newly acquired data from ancient DNA potentially answer questions of gene flow among these geographically disparate peoples. Keyser-Tracqui et al. (2003, 2006) analyzed aDNA from the Egiin Gol necropolis and found a close biological relationship between the ancient Egiin Gol sample and modern Mongolian samples. These researchers posit minimal genetic substructuring between different Mongolian populations reflecting the maintenance of a common genetic pool from the Iron Age to the present. However, they also found a distinct non-local Turkish genetic signature from the Egiin Gol necropolis. Kim et al. (2010) found the presence of a distinct 
paternal genetic signature known as haplogroup R1a1 in another elite Xiongnu cemetery. R1a1 is the most common paternal haplogroup in Europe (Malyarchuk, 2004). They also found the mtDNA haplogroup U2e, which is found mostly in central Asian populations (Comas et al., 2004). These distinct ancient genetic haplogroups tentatively support the archaeological evidence for not only material exchange, but also potentially mate exchange between the Xiongnu and Western Eurasian groups, or a common population history of peoples from Mongolia, Southern Siberia and Western Eurasia.

Keyser et al. (2009) also found evidence of the R1a1 haplogroup in a sample dated from between the middle of the second millennium BC to the fourth century AD in southern Siberia (Keyser et al., 2009). Using phenotype-informative single nucleotide polymorphisms (SNPs), these authors suggest that this region was predominately settled by European-like peoples who had blue eyes, fair skin, and light hair. These observations are expected, considering Indo-Europeans were likely resident in Northwest China close to 4,000 years ago (Yao et al., 2004). Accordingly, then, it would suggest the Western Eurasian Xiongnu male in the Kim et al. (2010) study was extant to Xiongnu homelands for approximately 2,000 years, and thus a long history of admixture between disparate groups.

Studies of aDNA into Xiongnu population history answer questions for a small, but significant, number of individuals who composed this incipient steppe empire. However, questions still remain about their origins that ancient DNA has not been able to answer sufficiently. The present study includes a greater number of individuals from this period in order to answer questions of regional population history of not only the Xiongnu, but also greater NE Asia. A craniometric assessment using methods of geometric morphometrics has the potential to fill in gaps left unexplored by the analysis of ancient DNA. Though several studies have analyzed skeletal remains of the Xiongnu peoples, a common understanding of their origins and their relationship to other nomadic groups has yet to be reached (Tumen, 2006, 2008; Lee, 2007, 2013; Lee and Zhang, 2013). Additionally, the population history of Mongolia from the Bronze Age to the present has yet to be fully explored, especially through the use of geometric morphometrics.

This study tests the null hypothesis of Xiongnu biological continuity (maintenance of a common biological pool) from the Iron Age to the present in order to explain Xiongnu origins and biological connections. The alternative hypothesis 
would suggest that if evidence for biological discontinuity were observed among Mongolian samples, then the explanation for substantial biological exchange between Xiongnu elite and other Eurasian groups would be strengthened. A quantitative assessment of Xiongnu skeletal remains has the potential to confirm earlier findings based on morphology or ancient DNA data. Various historical, cultural, and biological processes have shaped the diversity of the region today. To understand how these processes have shaped the region, this study examines past populations and tests how patterns of kinship and confederation forged the biogenetic makeup among modern Inner Asian peoples. The primary purpose of this study is to define the origins of the Xiongnu and gain insight into its population history and structure using craniofacial variation.

\section{Materials and Methods}

\subsection{Cranial series}

The materials used in this study are from osteological collections located in China, Mongolia, France, Russia, Japan, and the United States (Table 1). The first author collected cranial coordinate data on a total of 998 adult male and female crania. Xiongnu crania were sampled from several locations, including a site called Egiin Gol, specifically the cemetery of Borkhan Tolgoi. The individuals from the Egiin Gol site in this study differ from those used in a previous study of non-metric cranial variation by Ricaut et al. (2010) and an ancient DNA study by Keyser-Tracqui et al. (2003). In addition, we lack contextual information about what part of the necropolis individuals used in our study were buried. Therefore, we are unable to examine intra-cemetery variation in the same way Keyser-Tracqui et al. (2003) and Ricaut et al. (2010) did in their previous analyses. Other Xiongnu samples were pooled from various geographical locations around Mongolia, including central and eastern, and western Mongolia.

Bronze Age crania from Mongolia, China, and Siberia (BC 4500 - BC 700), Iron Age crania from China and Siberia (BC 700 BC - BC 300), Medieval Period crania from Mongolia and Siberia (AD 1100 - AD 1500), and modern period crania (AD 1800-present) from Mongolia, China, Siberia, Central Asia, Europe and Africa are included in order to test the hypothesis of biological continuity among Mongolian peoples and infer population history of the Xiongnu. Male and female crania from each sample were pooled in order to increase sample size. Information about 
archaeological provenience and dating of crania were obtained either from curatorial staff at the institutions from which data were collected, or through the published literature (see Table 1 for references in the literature that use individuals from the same cranial series).

\subsection{Cranial measurements}

A total of 44 coordinate points were initially observed for each skull; however, 24 coordinate points were used in the final analyses due to missing data or poor preservation (Table 2). The cranial landmarks selected for analysis include landmarks that capture overall shape dimensions of the crania, upper face, and nasal variation. These landmarks are common in studies of craniofacial diversity (Martin and Saller, 1957; Howells, 1973; Brace and Hunt, 1990; von Cramon-Taubadel, 2009). Coordinate data were collected using a MicroScribe G2X portable digitizer (Immersion Corporation, San Jose, CA) by the first author. Following data formatting, all subsequent geometric morphometric analyses (GMM) were carried out using the software package MorphoJ (Klingenberg, 2011). Individuals were subjected to a full Procrustes fit (GPA) and a covariance matrix was generated for further multidimensional analyses, including principal components (PCA) and discriminant function analysis. GPA allows for the separation of a size component (centroid size) from shape. Therefore, the emphasis is on shape rather than size. For example, all PCA derive residuals from the Procrustes coordinates derived from the covariance matrix, not from the centroid size. This procedure was used due to our pooling of male and female crania, which exhibit substantial size differences (Jantz et al., 2013).

\subsection{Analytical methods}

In our study, we analyze Xiongnu population history using temporal-spatial samples located in Mongolia, China, Siberia, and various locations in Central Asia. We chose to analyze craniofacial variation of the Xiongnu by including regional samples separately. That is, the inclusion of samples more similar or more different may bias shape variation among groups. Therefore, we wanted to know if the Xiongnu, when compared with these different geographic regions, show more similarity to some samples than others. To this end, we display results for each stratified level of analysis, including a "local" comparison with only samples that derive from Mongolia to test intra-group heterogeneity and the extent of a common 
gene pool, a "global" level analysis whereby samples from all over the Old World are included to place the Xiongnu and other Mongolian samples into a regional context, and a "regional" level analysis whereby the samples that derive from Mongolia are compared to samples (both ancient and modern) from 1) China, 2) Central Asia, and 3) Siberia in order test possible gene flow between these various interaction spheres. See Table 1 for which samples are included in which level analysis.

Principal components scores from the Procrustes residuals were utilized as new shape variables in order to construct craniometric affinity matrices as described in Roseman and Weaver (2004) and von Cramon-Taubadel (2009, 2011). The total number of principal components used for each analysis included those that captured at least $95 \%$ of the variance, which is similar to the analytical procedure used by von Cramon-Taubadel (2009). Individual PC scores were then used in the R-matrix analysis (see below). The R-matrix generated distance matrices for groups (R-matrix distances), which were then visualized as phylogenetic trees using the Mesquite package (Maddison and Maddison, 2014). All phylogenetic trees in this study were constructed using the tree inference command in the Mesquite package, which allows the software to heuristically search for the best possible tree among many using a single linkage method and maximum parsimony approach.

The R-matrix method (Relethford and Blangero, 1990) was used to estimate regional variation in quantitative phenotypic traits. The R-matrix has properties that make it useful to the study of population structure. This includes an estimate of interpopulation variation represented by an analogous measure of Wright's FST (genetic differentiation); the elements are easily transformed into genetic distances as $d^{2}=r_{i i}+$ $r_{j j}-2 r_{j i}$; the diagonal elements of the R-matrix reflect a distance to group "centroid", defined in terms of the average phenotypic measures over all populations; and under conditions of equilibrium between gene flow and genetic drift, the expected variation in population $i$ and the distance from the centroid represented as rii are expected to be linearly related (Relethford and Harpending, 1994; Hanihara and Ishida, 2009). Relethford and Blangero (1990) have shown that deviations from this model of local population structure can be attributed to differences in the rate of long-range gene flow. Therefore, a population with greater long-range gene flow will display greater within-group variation than expected, while a population exhibiting genetic drift or isolation will show less within-group variation than expected. 
The R-matrix method requires an estimate of average heritability for cranial traits and an estimate of effective population size for each group and/or geographic region. Cranial traits have shown a moderate heritability (0.55) based on several studies (Carson, 2006; Martinez-Abadias et al., 2009). A value of 1.0 can also be used to test for minimum genetic distance (Williams-Blangero and Blangero, 1989). Relethford and Blangero (1990) have shown that using a heritability of 1.0 only changes the magnitude of differentiation, not the actual distances among groups. This study makes use of both a moderate heritability (0.55) and minimum biological distance (1.0). Since population size is unknown for the groups used in this study, we use a scaled, unbiased R-matrix to account for genetic drift in small populations with the elements $g\left(\sqrt{w_{i}}\right)\left(\sqrt{w_{j}}\right)\left(r_{i j}\right)$, where $g$ is the number of populations and $w$ is the relative weight of populations $i$ and $j$. All populations were given equal weighting in the analyses.

Geographic (great circle distance) and temporal distances were constructed between populations to assess information about the correlation correspondence in overall variation for different sources of variability. Temporal distance matrices were constructed using median time periods for the samples under analysis. The $n \times n$ matrix was constructed to be the same size as the biological and geographic distance matrices. Geographic distances were calculated in PASSaGE 2 (Rosenberg and Anderson, 2011) using latitude and longitude coordinates for each sample. Geographic distance matrices were calculated as two-dimensional spherical distances from coordinate data. All distance matrices were then tested for correlation using the Mantel test or Partial Mantel test (Mantel, 1967; Smouse et al., 1986). Mahalanobis $\mathrm{D}^{2}$ distances were used as biological distances for testing. Significant difference between matrices was tested using 10,000 permutations.

Konigsberg (1990) explicated and formally developed the theoretical underpinning of space-time variation for chronologically defined archaeological skeletal samples. Using Konigsberg's (1990) results from the migration matrix and the stepping stone models as a basis for analyzing regional variation across time and space in prehistoric samples, the isolation by distance model predicts that if groups conform to such a model (IBD), then genetic and spatial distance should be positively correlated (when controlling for temporal distance), while genetic and temporal distance will be negatively correlated (when controlling for spatial distance). 


\section{Results}

As the origins of the Xiongnu are unknown, and pooling potentially biologically heterogeneous samples into one group may bias interpretation, it was essential to first explore intra-group heterogeneity in order to understand within-group population structure. This analysis consisted of clustering individual crania from Mongolian samples and a comparison based on R-matrix distances between Mongolian groups. A hierarchical approach was then taken, in that the Xiongnu were compared with a global cranial series that included outlier groups from Europe and Africa, and regional comparisons with samples from China, Central Asia, and Siberia in order to examine broader population history.

\section{1 "Local” Analysis: Within-group Mongolian population structure}

The use of the umbrella term Xiongnu most likely included multiple ethnicities, which may or may not correlate with differences in craniofacial variability. In this study, we include Xiongnu crania from several different areas in Mongolia, including several individuals from a single necropolis located in Northern Mongolia. Trees were constructed based on PC scores for individual crania from Mongolian samples and a phylogenetic tree based on R-matrix distances between Mongolian groups (Fig. 2). Although between-group variance is low, a cluster seems to emerge whereby all of the Egiin Gol individuals (Borkhan Tolgoi cemetery) are clustered with a majority of Bronze Age Chandman and the Mongol Turks, though there are also other Mongolian samples included within this cluster, as well as some Bronze Age individuals who are more closely related to the pooled Xiongnu, Mongol Period and Mongol Modern individuals (Fig. 2A). The majority of the pooled Xiongnu crania not from Egiin Gol all cluster with the Mongol Period and Modern Mongol crania. When sample variance is compared using R-matrix distances, both the Mongol Turk and Egiin samples are outliers (Fig. 2B). The Relethford-Blangero analysis suggests biological variation to be low among all Mongolian samples $\left(h^{2}=1.0, F_{S T}=0.07\right.$, results not shown). This result suggests the majority of the cranial variation is within each sample, not between them even though there appears to be some structuring of Xiongnu crania.

We then applied a discriminant function analysis specifically to the pooled Xiongnu and Egiin Gol samples to better understand exact morphological differences 
(results not shown). We found that in a leave-one-out cross validation test, almost all of the individuals group into their respective samples. That is, all but two Egiin Gol individuals group with the Egiin Gol sample. Although we employ 3D coordinate data, our results suggest that localized shape variation associated with the upper face may be driving the morphological distinction between these Xiongnu samples, though caution must be exercised considering the small sample size of the Egiin Gol sample. Based on these results, the Egiin Gol sample was not pooled with other Xiongnu crania and analyzed separately for all additional comparisons.

\section{2 "Global” Analysis: Xiongnu comparison to a global cranial series}

To evaluate the relationship of the Xiongnu to groups in the region (China, Siberia, Central Asia), a phylogenetic tree was constructed from R-matrix distances, which also included European and African samples as outlying comparison populations (Fig. 3). What emerges in this tree is a distinct clustering of the Bronze Age Chandman, Mongol Turk, and Xiongnu Egiin Gol samples with the Ainu and ancient Jomon of Japan. A trend also appears in the tree where many (but not all) groups cluster with other like temporal series. For example, all of the ancient Chinese samples cluster together, while the ancient Siberian samples group together into a larger cluster that includes the pooled Xiongnu, the modern Mongol, and the Medieval Mongol samples. However, the Kazakh and Yakut series also cluster with the Mongolian samples. We tested whether the temporal component was correlated with biological variation using a Partial Mantel test (Table 3). As expected of samples that may conform to an isolation-by-distance model, spatial distance was significantly correlated with morphological distance; however, interestingly, temporal distance (while holding geographic distance constant) was not.

\section{3. "Regional" Analysis: Comparisons with Chinese, Central Asian, and Siberian cranial series}

We conducted separate Relethford-Blangero and R-matrix distance analyses for our Mongolian samples and compared them with both modern and ancient samples that derive from China, Central Asia, and Siberia (Tables 4, 5, and 6). The Relethford-Blangero tests were all similar, in that the unbiased FST using a heritability of 0.55 was moderate (average 0.34 ). This result is most likely being driven by the divergence of the Mongolian Bronze Age Chandman, Mongol Turk, and Egiin Gol 
samples. In addition, sample size is low among several samples, including the sample from India and the Chuckchi from Siberia. In terms of distance to the centroid ( $\mathrm{r}_{\mathrm{ii}}$ ), the three closest samples to the pooled Xiongnu include the Liaoning sample from China, which is a sample of Xianbei Iron Age nomads, the Kazakh sample from Central Asia, and the Iron Age Tuva sample from Siberia. All pooled Xiongnu residuals are negative, indicating some degree of genetic drift or isolation, while the Egiin Gol sample displays positive residuals, indicating that perhaps these Xiongnu individuals were receiving gene flow from other samples not included in these analyses.

The phylogenetic trees constructed from R-matrix distances between samples for each of the three regional analyses show a consistent grouping of the Egiin Gol Xiongnu, Bronze Age Mongolian Chandman, and the Mongol Turk samples (Figure 4). However, the trees also display some interesting results. The Chinese comparison places the Xiongnu into a loose cluster that contains the Liaoning and Qinghai samples (Figure 4A). The Central Asian tree comparison (Figure 4B) splits the samples into two clusters. One of these clusters contains all of the Mongolian samples, except the pooled Xionngu, plus the Kazakh. The pooled Xionngu occupy an intermediate position between the two clusters. The Siberian comparison (Figure 4C) is more complex. Here, the Chandman Bronze Age sample from Mongolia cluster with the Chuckchi, while the pooled Xiongnu sample occupies an intermediate position, similar to the Central Asian comparison. The Mongol modern sample is also positioned between other Siberian samples (Buryat and Yakut), possibly indicating a greater shared history between these Mongolian and Siberian groups.

\section{Discussion}

Only recently have researchers begun to unravel the complex history of Mongolia's peoples and places (Sabloff, 2011; Schurr and Pipes, 2011). The formation of the Mongolian people involved a series of complex demographic processes that included a diverse mix of confederations, clans, tribes, and families. The results from this study have shown a complex population structure for the nomadic Xiongnu peoples, evidenced in craniofacial variation.

\section{1 "Local" level analysis suggests possible population structure amongst Xiongnu individuals}


Our results suggest the possibility of two separate biological clusters of Xiongnu individuals. However, our results also show that there is a mix of individuals from different time periods within each cluster, something we should expect if these spatio-temporal samples derive from a single genetic pool (Fig. 2A). The first cluster contains individuals from the Egiin Gol Xiongnu sample from northern Mongolia, the Bronze Age Chandman sample, and the Mongol Turk ( 8th century AD) sample, though this sample is very small. The second cluster contains the modern Mongolian, Mongol Period, and the pooled Xiongnu sample (Fig. 2A). Results from the Relethford-Blangero analysis show that much of the variation is within these samples, not between them, and the R-matrix distances are relatively small (Fig. 2B). Due to a consistent clustering of the Egiin Gol individuals from the other known Xiongnu individuals, we chose to include the Egiin Gol sample as a separate group in all further analyses.

The Xiongnu polity was composed of elite agents in an effort to control an administrative territory that stretched from Xinjiang Province in China to south Siberia. Based on their separation from other Xiongnu individuals, the Egiin Gol sample may represent an isolated element within Xiongnu society, while the other pooled Xiongnu sample may include individuals who composed the majority of its peoples. Or, perhaps the Egiin Gol sample is not entirely representative of the Xiongnu people, and those individuals should be considered an initial wave of peoples who made up the Turk (Uyghur) Empire that dominated parts of Mongolia beginning in the 8 th century $\mathrm{AD}$. The pooled Xiongnu sample based on our craniometric analyses shows a clear relationship to both the Mongol period sample and the modern Mongolian sample. This finding would suggest that at least some individuals who composed the Xiongnu steppe polity are connected biologically to peoples who composed the Mongol Empire under Genghis Khan, and to individuals who now compose the modern nation-state of Mongolia. This result reinforces the observation of a common gene pool from the Iron Age to the present.

The exact morphological differences that may be driving the Xiongnu samples separation are difficult to interpret since we use 3D coordinate data. However, Jantz et al. (2013) found that the first two or three principal components account for a significant amount of shape variation between male and female skulls. Though we pooled our samples using both male and females, we removed much of the size variation associated with sexually dimorphic differences. We conducted a 
discriminant function analysis between the Egiin Gol and pooled Xiongnu and found that characteristics associated with the upper face, specifically, upper facial breadth, may explain the differences, though we exercise caution in this interpretation since our sample sizes are relatively small.

The Egiin Gol sample comes from the Borkhan Tolgoi cemetery, which has been previously studied (Murail et al., 2000; Keyser-Traqui et al., 2003; Crubezy et al., 2006; Wright, 2006; Wright et al., 2009; Ricaut et al., 2010). This necropolis was used during the entire Xiongnu period and contains the remains of 84 graves containing skeletal material from 99 individuals (Fig. 5). It was arranged into three main sections that roughly correspond to temporal ordering. Section A is the oldest followed by Section B and Section C. Section A contains a number of "double burials" near graves marked with higher status individuals (Murail et al., 2000). This practice was quite common among peoples of the Scytho-Siberian tradition, including the Yakuts and the Bronze Age Pazyryk culture of the Gorny Altai in southern Siberia (Chikisheva, 2000, 2008; Ricaut et al., 2004a, 2004b; Amory et al., 2006).

Section $\mathrm{C}$ of the necropolis corresponds to the end of the cemetery's use and may be associated with a Turkish influence of the Xiongnu tribe (Keyser-Tracqui et al., 2003). Based on aDNA data, Keyser-Tracqui et al. (2003) found distinct signatures unique to this section of the necropolis. Specifically, they found distinct genetic markers of a Turkish origin and a characteristically kin grouping in Section C. Ricaut et al. (2010) also detected this unique signature in Section C using nonmetric cranial traits. Our sample consists of individuals from Borkhan Tolgoi, however, we were not able to include the exact individuals sampled in the genetic (Keyser-Tracqui et al. 2003, 2006) and the non-metric (Ricaut et al. 2010) studies. Therefore, we were not able to conduct an intra-cemetery analysis due to lack of context for Egiin Gol individuals. Regardless, the Egiin Gol individuals included in this study did show a characteristic outlier signature in the analyses, which may be similar to those results observed using ancient DNA and non-metric cranial data.

\section{2 "Global” level analysis places Xiongnu into larger Northern Eurasian regional context}

Results from our GMM global comparative analysis (using all populations) indicate that these populations mainly conform to an isolation-by-distance model (Wright, 1943) for global human variation that has been seen in other large-scale 
phenotypic studies (Betti et al., 2010). The isolation-by-distance phenomenon for modern human populations indicates that, as groups become more geographically separated, the genetic distance between them increases as a function of geographic distance. This is seen in major geographic groupings along the branches of the tree in Fig. 3. The Partial Mantel test also confirms this observation by indicating a significant correlation between geographic and biological distance while holding temporal distance constant (accounting for temporal variation) (Table 3). Although hierarchical trees are not the most appropriate representation of visualizing human relationships due to extensive admixture between populations, nonetheless, Fig. 3 does indicate some structuring amongst local samples. The Egiin Gol cluster seems to be more closely related to the prehistoric hunter-gatherer Jomon people and the modern Ainu of Japan than with other modern East Asian groups.

It has been suggested on the basis of genetic and morphological data, that the peopling of East Asia occurred along a southern route during the Paleolithic; however, some studies have suggested a Neolithic contribution to Northeast Asian groups from West Eurasia and Central Asia (Zhong et al., 2011). This is evident in our results showing clustering of southern Siberian and Mongolian samples with Central Asian and Northern European populations. Modern genetic studies have suggested a contribution of Neolithic expansions on Northeast Asian populations, including indigenous Siberian and Mongolian groups. Major Y chromosome haplogroups $\mathrm{Q}$ and $\mathrm{R}$ that derive from Western Eurasian populations have been detected in Northeast Asian groups, while several mtDNA haplogroups, such as $\mathrm{H}$ and V, show signatures of postglacial expansion into Northeast Asia (Derenko et al., 2007). These distinctive signatures have also been found in ancient skeletal remains from places such as southern central Siberia, the Tarim Basin and Xinjiang province in China (Lalueza-Fox et al., 2004; Ricaut et al., 2005; Keyser et al., 2009; Li et al., 2010; Zhang et al., 2010). Our pooled Xiongnu sample clusters with other known Central Asian and Siberian groups who harbor these genetic signatures. Thus, our morphological results seem to support a common population history for Northern Eurasian peoples that may be separate from modern East Asian peoples.

\section{3 "Regional" level analyses reveal differential shared population history with} samples from China, Central Asia, and Siberia 
When the Mongolian samples were compared with Chinese samples, we found a close association for the pooled Xiongnu sample and the Liaoning cemetery from Northeastern China (Table 4, Fig. 4A). The Liaoning sample dates from the second to third century AD (Chen, 2002; Wang et al. 2012). According to archaeological and historical evidence, the individuals buried at this cemetery might be the descendants of the Donghu people, who were a Mongolic nomadic people who occupied northeastern China and were conquered by the Xiongnu in $150 \mathrm{BC}$ (Wang et al. 2012). The Donghu were later subsumed under the Xianbei Empire, who are suggested to have historic ties to the Xiongnu and modern Mongolian peoples (Di Cosmo, 2002). These connections are most likely the result of historical and demographic processes that brought the Mongols into contact with sedentary populations living in Inner Mongolia. Our craniofacial analysis suggests these two nomadic groups have a shared biological history, which is also supported by ancient DNA data (Wang et al. 2007)

When we compared our Mongolian samples to modern-day Central and Southern Asian samples, we found some similarity to the Kazakh sample (Fig. 4B, Table 5). The Kazakhs are descendants of various Turkic tribes. In a study by Lalueza-Fox et al. (2004), the authors show that the Kazakh population is composed of West and East Eurasian mtDNA haplogroups. However, it was not until the expansion of the Xiongnu did the authors observe traces of East Eurasian haplotypes. The authors attribute these sequences to the migrations of the Xiongnu from Mongolia and Siberia. The Lalueza-Fox et al. (2004) study bears further evidence for the influence of the Turkic tribes on the Mongolian populations, or vice versa.

Lastly, the Mongolian samples were separately analyzed against a number of geographically and temporally distinct groups from Siberia. Our results indicate the Xiongnu (and modern Mongols) show some relationship with the modern Yakut (or Sakha) sample (Fig. 4C, Table 6), whom are a Turkic-speaking group with borrowed Mongolic words who reside in the modern republic of Yakutia, an autonomous region in Central and northeastern Siberia. The Yakut are semi-nomadic cattle and horse breeders surrounded by Tungustic-speaking reindeer herders (Evenks and Evens) and hunter-gatherers (Pakendorf et al., 1999). Evidence from mtDNA suggests the Yakuts are closely related to southern Siberian and Central Asian groups, which confirms a southern origin. The timing of their northward migration has been suggested as being caused by the expanding Mongol empire (Pakendorf et al., 2006). Both maternal 
(Zlojutro et al., 2008) and paternal (Pakendorf et al., 2006) lineages suggest a bottleneck event at around 800-1000 BP, very close to the founding of the Mongol Empire. Using aDNA taken from the Egiin Gol cemetery, Keyser-Tracqui et al. (2006) compared modern Yakut DNA with the ancient DNA from the Xiongnu. These authors found no evidence, on the basis of $\mathrm{Y}$ chromosomal analysis, for a link between Xiongnu and Yakut; however, some of the Xiongnu individuals had shared mtDNA sequences with modern Yakuts. The lack of Y chromosome similarity could be the result of a significant loss of genetic diversity in the Yakuts after their contact with the Mongol Empire, which probably resulted in significant loss of males to the gene pool, or could simply result from genetic processes, such as genetic drift.

Amory et al. (2006) characterized the aDNA of a single Yakut individual from the Altai-Baikal region near the Lena River and found the mitochondrial haplotype of this individual matched a woman buried at Egiin Gol cemetery. Crubezy et al. (2010) analyzed a more extensive aDNA sample from the 15th century and found that the male lineage was composed of a small group of settlers from the Cis-Baikal region and that the maternal lineage was more diverse and composed of groups from different south Siberian origins. Our results have shown a direct link between the Yakut, the Xiongnu, and modern Mongolian peoples based on craniofacial variability and have confirmed previous aDNA studies. This evidence highlights admixture events between peoples now living in central and northeastern Siberia, the Iron Age Xiongnu, and peoples who now inhabit modern-day Mongolia.

\section{Conclusions}

In trying to elucidate questions of Xiongnu origin and relationships, this study has shown the complex nature of group dynamics, historical demographic processes, and biological relationships that define the region of Inner Asia. We have shown possible variable origins and population structure for the Xiongnu, at least for one cemetery (Egiin Gol necropolis) in northern Mongolia during the Late Iron Age. These individuals may have administered parts of the Xiongnu Empire, or were among a wave of Turkish immigrants, who eventually came to dominate the Inner Asian steppe during the late 7 th and 8th centuries AD. On the other hand, the pooled sample of Xiongnu from east, west, and central Mongolia seem to integrate into and define a continuity of populations that have inhabited modern-day Mongolia for at 
least the last 2000 years. The finding of biological continuity in Mongolia reinforces previous research into the Xiongnu peoples (Keyser-Tracqui et al. 2006).

We also find that some of the pooled Xiongnu share morphological features that are similar to groups from the Iron Age to the present in China and Siberia. This result is not too surprising given the amount of mobility in the region and the potential for admixture to occur among both nomadic and sedentary populations. This finding is similar to what has been proposed elsewhere, and the similarities to some groups in China (Xianbei), Siberia (Yakut), and Central Asia (Kazakh) should help shape future research. Larger samples and additional analyses, including ancient DNA, may help clarify issues of origin and demography of the world's first steppe empire.

\section{Acknowledgements}

We would like to thank the museum curators for access to the skeletal collections: Wei Dong and Zhu Hong at Jilin University, Tumen Dashtseveg at the National University of Mongolia, Chunag Amartuvshin at the Mongolian Academy of Sciences Institute of Archaeology, Giselle Garcia-Park at the American Museum of Natural History, Philippe Mennecier at the Musée de l'Homme, Alisa Zubova at the Russian Academy of Sciences, Institute of Ethnography and Archaeology, Siberian Branch, Andrej Evteev at Lomonosov Moscow State University, and Gen Suwa and Osamu Kondo at the University Museum, University of Tokyo. We thank the Editor and two anonymous reviewers' comments, which greatly improved the final version of this manuscript. The first author would also like to thank Mary Margaret-Murphy for help with data formatting, Pauline Sebillard and Wen Zeng for help in Changchun, and Natasha Kharlamova for help in Moscow. This research was partially supported with a National Science Foundation Doctoral Dissertation Improvement Grant (BCS \#1028773).

\section{References}

Allard, F.D., Erdenebaatar, D., 2005. Khirigsuurs, ritual and mobility in the Bronze Age of Mongolia. Antiquity 79, 547-563.

Allard, F.D., Erdenbaatar, D., Batbold, N., Miller, B., 2002. A Xiongnu cemetery found in Mongolia. Antiquity 76, 637-638. 
Amory, S., Crubezy, E., Alekseev, A.N., Ludes, B., 2006. Early influence of the steppe tribes in the peopling of Siberia. Human Biology 78, 531-549.

Betti, L., Balloux, F., Hanihara, T., Manica, A., 2010. The relative role of drift and selection in shaping the human skull. American Journal of Physical Anthropology $141,76-82$.

Brace, C.L., Hunt, K.D., 1990. A nonracial craniofacial perspective on human variation: A(ustralia) to Z(uni). American Journal of Physical Anthropology 82, 341360.

Carson, E.A., 2006. Maximum likelihood estimation of human craniometric heritabilities. American Journal of Physical Anthropology 131, 169-180.

Chen S. 2002. The study on human skulls from Lamadong cemetery: In: Zhu H, ed. Research of China’s frontier archaeology. Beijing: Science Press. p. 314-322.

Chikisheva, T.A., 2000. Origins of the Early Iron Age nomads in Gorny Altai: physical anthropological evidence. Archaeology, Ethnology, and Anthropology of Eurasia 4, 107-121.

Chikisheva, T.A., 2008. The origin of the early nomadic populations of Tuva: craniometrical evidence. Archaeology, Ethnology, and Anthropology of Eurasia, 36, $120-139$.

Comas, D., Plaza, S., Wells, R.S., Yuldaseva, N., Lao, O., Calafell, F., Bertranpetit, J., 2004. Admixture, migrations, and dispersals in Central Asia: evidence from maternal DNA lineages. European Journal of Human Genetics 12, 495-504.

Crubezy, E., Ricaut, F.X., Martin, H., Erdenebaatar, S., Coqueugnot, H., Maureille, B., Giscard, P.H., 2006. Inhumation and cremation in medieval Mongolia: analysis and analogy. Antiquity 80, 894-905. 
Crubezy, E., Amory, S., Keyser, C., Bouakaze, C., Bodner, M., Gilbert, M., Rock, A., Parson, W., Alexeev, A., Ludes, B., 2010. Human evolution in Siberia: from frozen bodies to ancient DNA. BMC Evolutionary Biology 10, 25.

Derenko, M., Malyarchuk, B.A., Grzybowski, T., Denisova, G., Dambueva, I., Perkova, M., Dorzhu, C., Luzina, F., Lee, H.K., Vanecek, T., Villems, R., Zakharov, I., 2007. Phylogeographic analysis of mitochondrial DNA in northern Asian populations. American Journal of Human Genetics 81, 1025-1041.

Di Cosmo, N., 2002. Ancient China and its enemies: the rise of nomadic power in East Asia. Cambridge, Cambridge University Press.

Fu Y, Zhao H, Cui Y, Zhang Q, Xu X, Zhou H, Zhu H. 2007. Molecular genetic analysis of Wanggu remains, Inner Mongolia, China. American Journal of Physical Anthropology 132, 285-291.

Hall, M., Batsaikhan, Z., Honeychurch, W., 1999. Radiocarbon dates from northern Mongolia. Radiocarbon 41, 103-110.

Hanihara, T., Ishida, H., 2009. Regional differences in craniofacial diversity and the population history of Jomon Japan. American Journal of Physical Anthropology 139, 311-22.

Honeychurch, W., 2003. Inner Asian warriors and khans: a regional spatial analysis of nomadic political organization and interaction. $\mathrm{PhD}$ dissertation, The University of Michigan.

Honeychurch, W., Amartuvshin, C., 2006. States on horseback: the rise of Inner Asian confederations and empires. In, Stark M, ed. Archaeology of Asia. Blackwell, Malden (MA).

Houle, J., 2010. Emergent complexity on the Mongolian steppe: mobility, territoriality, and the development of early nomadic polities. $\mathrm{PhD}$ dissertation, University of Pittsburgh. 
Howells, W.W., 1973. Cranial variation in man: a study by multivariate analysis of patterns of differences among recent human populations. Papers of the Peabody Museum of Archaeology and Ethnology, Vol. 67. Cambridge, MA: Peabody Museum.

Jantz, R.L., Mahfouz, M., Shirley, N.R., Fatah, E., 2013. Improving sex estimation from crania using 3-dimensional CT scans. Final Technical Report: Department of Justice.

Keyser, C., Bouakaze, C., Crubezy, E., Nikolaev, V.G., Montagnon, T., Ludes, B., 2009. Ancient DNA provides new insights into the history of south Siberian Kurgan people. Human Genetics 126, 395.410.

Keyser-Tracqui, C., Crubezy, E., Ludes, B., 2003. Nuclear and mitochondrial DNA analysis of a 2,000-year-old necropolis in the Egyin Gol valley of Mongolia. American Journal of Human Genetics 73, 247-260.

Keyser-Tracqui, C., Crubezy, E., Pamzsav, H., Varga, T., Ludes, B., 2006. Population origins in Mongolia: genetic structure analysis of ancient and modern DNA. American Journal of Physical Anthropology 131, 272-281.

Kim, K., Brenner, C.H., Mair, V.H., Lee, K.H., Kim, J.H., Gelegdorj, E., Batbold, N., Song, Y., Yun, H., Chang, E., Lkhagvasuren, G., Bazarragchaa, M., Park, A., Lim, I., Kim, S., Lee, W., Kim, K., 2010. A western Eurasian male is found in 2000-year old elite Xiongnu cemetery in northeast Mongolia. American Journal of Physical Anthropology 142, 429-441.

Klingenberg, C., 2011. MorphoJ: an integrated software package for geometric morphometrics. Molecular Ecology Resources 11, 353-357.

Konigsberg, L. W., 1990. Temporal aspects of biological distance: Serial correlation and trend in a prehistoric skeletal lineage. American Journal of Physical Anthropology 82, 45-52. 
Lalueza-Fox, C., Sampietro, M.L., Gilbert, M.T.P., Castri, L., Facchini, F., Pettener, D., Bertranpetit, J., 2004. Unraveling migrations in the steppe: mitochondrial DNA sequences from ancient Central Asians. Proceedings of the Royal Society London B 271, 941-947.

Lee, C. 2007. The biological affinities of Neolithic through modern period populations from China and Mongolia: the cranial and dental nonmetric evidence. PhD dissertation: Arizona State University.

Lee, C. 2013. The population history of China and Mongolia from the Bronze Age to the Medieval Period (2500 BC-AD 1500). In K. Pechenkina and M. Oxenham (Eds). Bioarchaeology of East Asia: Movement, Contact, Health. University Press of Florida, Gainesville. p. 61-84.

Lee, C., Zhang, L. 2013. Do all Asians look alike? A dental nonmetric analysis of population diversity at the dawn of the Chinese Empire (770 BC-420 AD). In G.R. Scott and J. Irish (Eds). Anthropological Perspectives on Tooth Morphology: Genetics, Evolution, Variation. Cambridge University Press, Cambridge. p. 388-407.

Li, C., Li, H., Cui, Y., Xie, C., Cai, D., Li, W., Mair, V.H., Zhang, Q., Abuduresule, I., Jin, L., Zhu, H., Zhou, H., 2010. Evidence that a west-east admixed population lived in the Tarim Basin as early as the Early Bronze Age. BMC Biology 8, 15.

Maddison, W. P., Maddison, D.R., 2014. Mesquite: a modular system for evolutionary analysis. Version 3.01. http://mesquiteproject.org

Malyarchuk, B.A., 2004. Differentiation of the mitochondrial subhaplogroup U4 in the populations of Eastern Europe, Ural, and Western Siberia: implication to the genetic history of the Uralic populations. Russian Journal of Genetics 40, 1281-1287.

Martin, R., Saller, K., 1957. Lehrbuch der Anthropologie. Third Edition. Gustav Fisher, Stuttgart. 
Martinez-Abadias, N., Esparza, M., Sjovold, T., Gonzalez-Jose, R., Santos, M., Hernandez, M., 2009. Heritability of human cranial dimensions: comparing the evolvability of different cranial regions. Journal of Anatomy 214, 19-35.

Miller, B.K., 2009. Power politics in the Xiongnu empire. PhD dissertation, University of Pennsylvania.

Morgan, D., 1986. The Mongols. Oxford, Blackwell.

Murail, P., Crubezy, E., Martin, H., Haye, L., Bruzek, J., Giscard, P.H., Turbat, T., Erdenebaatar, D., 2000. The man, the woman and the hyoid bone: from archaeology to the burial practices of the Xiongnu people (Egyin Gol valley, Mongolia). Antiquity 74, 531-536.

Pakendorf, B., Spitsyn, V.A., Rodewald, A., 1999. Genetic structure of a Sakha population from Siberia and ethnic affinities. Human Biology 71, 231-244.

Pakendorf, B., Novgorodov, I.N., Osakovskij, V.J., Danilova, A.P., Protod'jakonov, A.P., Stoneking, M., 2006. Investigating the effects of prehistoric migrations in Siberia: genetic variation and the origins of Yakuts. Human Genetics 120, 334-353.

Relethford, J.H., Blangero, J., 1990 Detection of differential gene flow from patterns of quantitative variation. Human Biology 62, 5-25.

Relethford, J.H., Harpending, H.C., 1994. Craniometric variation, genetic theory, and modern human origins. American Journal of Physical Anthropology 95, 249-270.

Ricaut, F.X., Kolodesnikov, S., Keyser-Tracqui, C., Alekseev, A.N., Crubezy, E., Ludes, B., 2004a. Genetic analysis of human remains found in two eighteenth century Yakut graves at At-Dabaan. International Journal of Legal Medicine 118, 24-31.

Ricaut, F.X., Keyser-Tracqui, C., Cammaert, L., Crubezy, E., Ludes, B., 2004b. Genetic analysis and ethnic affinities from two Scytho-Siberian skeletons. American Journal of Physical Anthropology 123, 351-360. 
Ricaut, F.X., Fedoseeva, A., Keyser-Tracqui, C., Crubezy, E., Ludes, B., 2005. Ancient DNA analysis of human Neolithic remains found in Northeastern Siberia. American Journal of Physical Anthropology 126, 458-462.

Ricaut, F.X., Auriol, V., von Cramon-Taubadel, N., Keyser, C., Murail, P., Ludes, B., Crubezy, E., 2010. Comparison between morphological and genetic data to estimate biological relationships: the case of the Egyin Gol necropolis (Mongolia). American Journal of Physical Anthropology 143, 355-365.

Roseman, C.C., Weaver, T.D., 2004. Multivariate apportionment of global human craniometric diversity. American Journal of Physical Anthropology 125, 257-263.

Rosenberg, M.S., Anderson, C.D., 2011. PASSaGE: pattern analysis, spatial statistics, and geographic exegesis. Version 2. Methods in Ecology and Evolution 2, 229-232.

Sabloff, P.L.W., editor, 2011. Mapping Mongolia: situating Mongolia in the world from geologic time to the present. University of Pennsylvania Museum of Archaeology and Anthropology, Philadelphia.

Schurr, T.G., Pipes, L., 2011. The prehistory of Mongolian populations as revealed by studies of osteological, dental, and genetic variation. In, Sabloff, P., editor. Mapping Mongolia: situating Mongolia in the world from geologic time to the present. University of Pennsylvania Museum of Archaeology and Anthropology, Philadelphia. p.125-166.

Smouse, P., Long, J., Sokal, R., 1986. Multiple regression and correlation extensions of the Mantel test of matrix correspondence. Systematic Zoology 35, 627-632.

Tumen, D., 2006. Paleoanthropology of ancient populations of Mongolia. Mongolian Journal of Anthropology, Archaeology, and Ethnology 2, 90-108.

Tumen, D., 2008. Anthropology of archaeological populations from Inner Asia. Mongolian Journal of Anthropology, Archaeology, and Ethnology 4, 162-183. 
von Cramon-Taubadel, N., 2009. Congruence of individual cranial bone morphology and neutral molecular affinity patterns in modern humans. American Journal of Physical Anthropology 140, 205-215.

von Cramon-Taubadel, N., 2011. The relative efficacy of functional and developmental cranial modules for reconstructing global human population history. American Journal of Physical Anthropology 146, 83-93.

Wang, H., Ge, B., Mair, V.H., Cai, D., Xie, C., Zhang, Q., Zhou, H., Zhu, H., 2007. Molecular genetic analysis of remains from Lamadong cemetery, Liaoning, China. American Journal of Physical Anthropology 134, 404-411.

Wang, H., Chen, L., Ge, B., Zhang, Q., Zhu, H., Zhou, H., 2012. Genetic data suggests the Jinggouzi people are associated with the Donghu, an ancient nomadic group of North China. Human Biology 84, 355-378.

Williams-Blangero, S., Blangero, J., 1989. Anthropometric variation and the genetic structure of the Jirels of Nepal. Human Biology 61, 1-12.

Wright, J., 2006. The adoption of pastoralism in Northeast Asia: monumental transformation in the Egiin Gol valley, Mongolia. PhD dissertation, Harvard University.

Wright, J., Honeychurch, W., Amartuvshin, C., 2009. The Xiongnu settlements of Egiin Gol, Mongolia. Antiquity 83, 372-387.

Wright, S., 1943. Isolation by distance. Genetics 28, 114-137.

Yao, Y., Kong, Q., Wang, C., Zhu, C., Zhang, Y., 2004. Different matrilineal contributions to genetic structure of ethnic groups in the Silk Road region in China. Molecular Biology and Evolution 21, 2265-2280. 
Zhang, F., Xu, Z., Tan, J., Sun, Y., Xu, B., Li, S., Zhao, X., Zhou, H., Gong, G., Zhang, J., Jin, L., 2010. Prehistorical east-west admixture of maternal lineages in a 2,500 year-old population in Xinjiang. American Journal of Physical Anthropology 142, 314-320.

Zhong, H., Shi, H., Qi, X., Duan, Z., Tan, P.P., Jin, L., Su, B., Ma, R.Z., 2011. Extended $\mathrm{Y}$ chromosome investigation suggests postglacial migrations of modern humans into East Asia via the northern route. Molecular Biology and Evolution 28, 717-727.

Zlojutro, M., Tarskaia, L.A., Sorensen, M., Snodgrass, J.J., Leonard, W.R., Crawford, M.H., 2008. The origins of the Yakut people: evidence from mitochondrial DNA diversity. International Journal of Human Genetics 8, 119-130.

Zubova, A.V., 2008. The paleodemography of western Siberia in the middle and Late Bronze Age. Archaeology, Ethnology, and Anthropology of Eurasia, 34. 143-153.

Zubova, A.V., 2013. Dental affinities of the Irmen people, western Siberia. Archaeology, Ethnology, and Anthropology of Eurasia, 41, 132-139.

\section{Figure Legends}

Figure 1. Iron Age archaeological cultures of Mongolia, NE China, and Southern Siberia discussed throughout the article. We present these as representative of potential overlap amongst these geographically disparate Iron Age nomadic peoples.

Figure 2. Phylogenetic trees for "local" comparative analysis. (A) Individual Mongolian crania are clustered based on individual principal components scores. $\mathrm{Brz}$, Chandman Bronze Age; Eg, Egiin Gol Xiongnu; $M e d$, Pooled Mongol Period; $M g$, Pooled Mongol Modern; Xn, Pooled Xiongnu Period, Trk, Mongol Turk Period. (B) Phylogenetic tree of Mongolian groups. Trees constructed from R-matrix distances using a single linkage method and maximum parsimony approach. For sample colors, see online edition of this article. 
Figure 3. Phylogenetic tree for "global" comparative analysis. Tree constructed from R-matrix distances using a single linkage method and maximum parsimony approach. For sample colors, see online edition of this article.

Figure 4. Phylogenetic trees for "regional" comparative analysis. (A) Mongolian samples compared only with Chinese samples. (B) Mongolian samples compared only with Central Asian samples. (C) Mongolian samples compared only with Siberian samples. All trees constructed from R-matrix distances using a single linkage method and maximum parsimony approach.

Figure 5. Map showing location of Xiongnu Egiin Gol cemetery (adapted from Ricaut et al. 2010). Inset shows the three sections of the cemetery corresponding to radiocarbon dating. Note the individuals included in this article do not have contextual information as to their location $(\mathrm{A}, \mathrm{B}$, or $\mathrm{C})$ in the cemetery. 

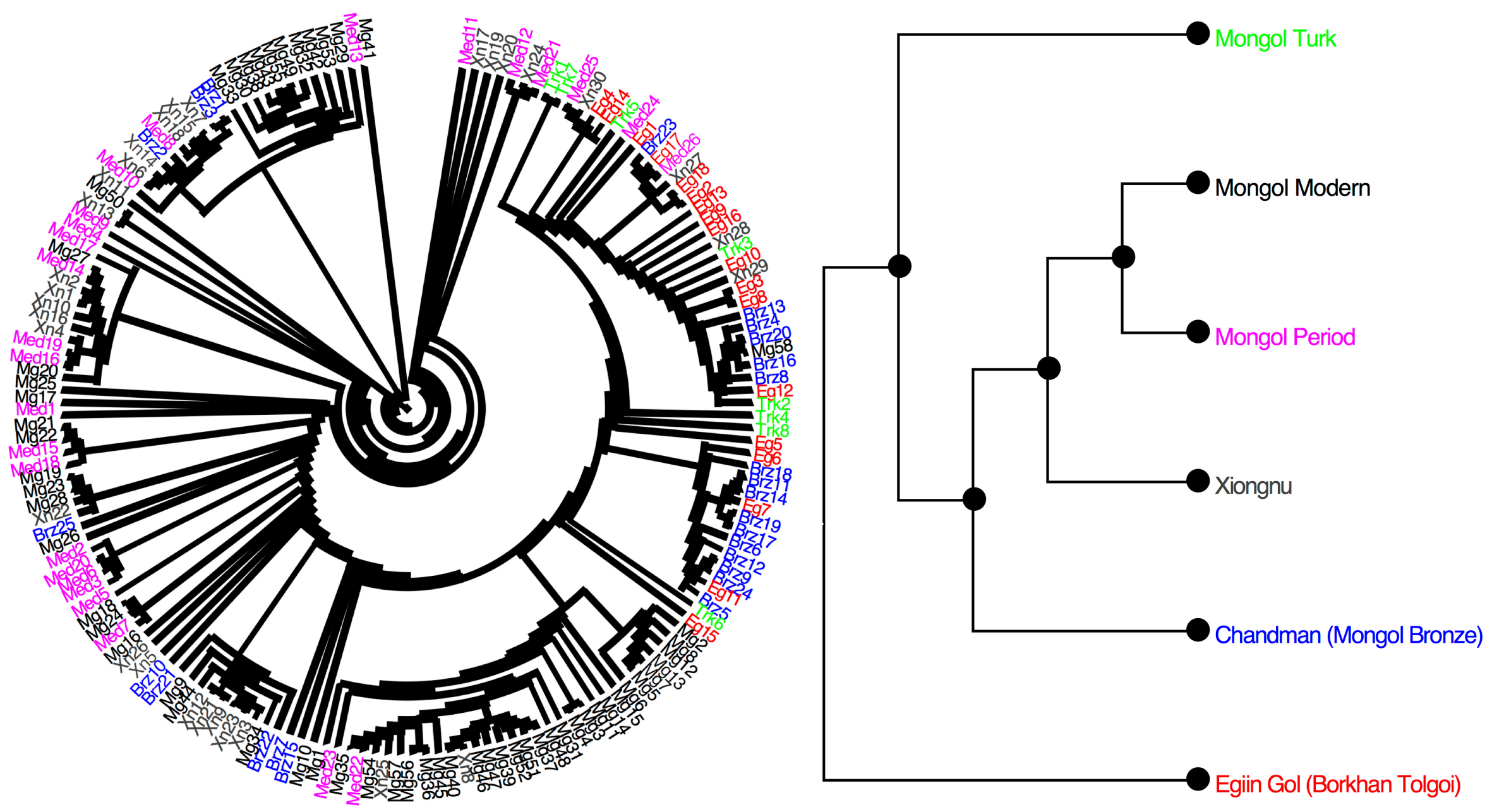


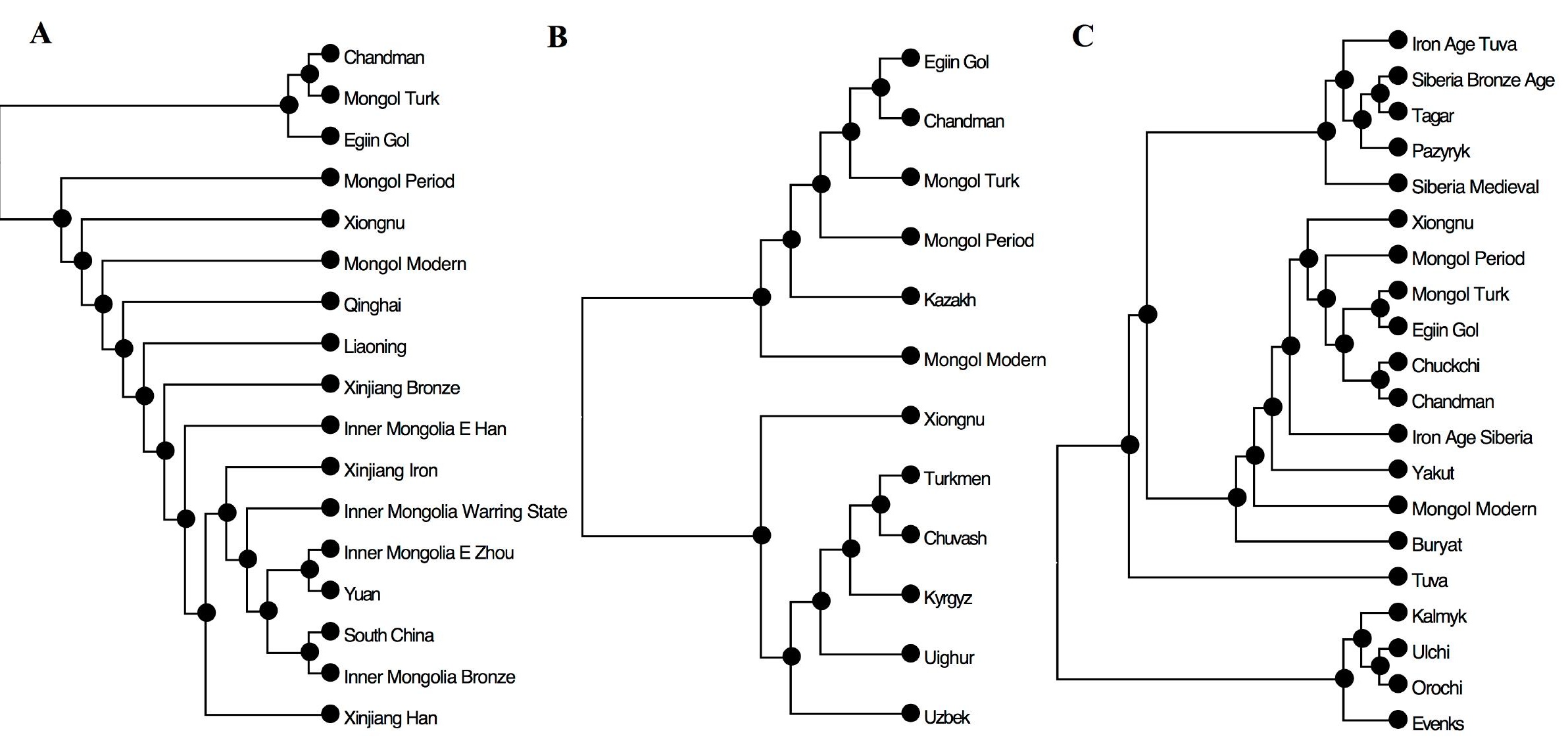




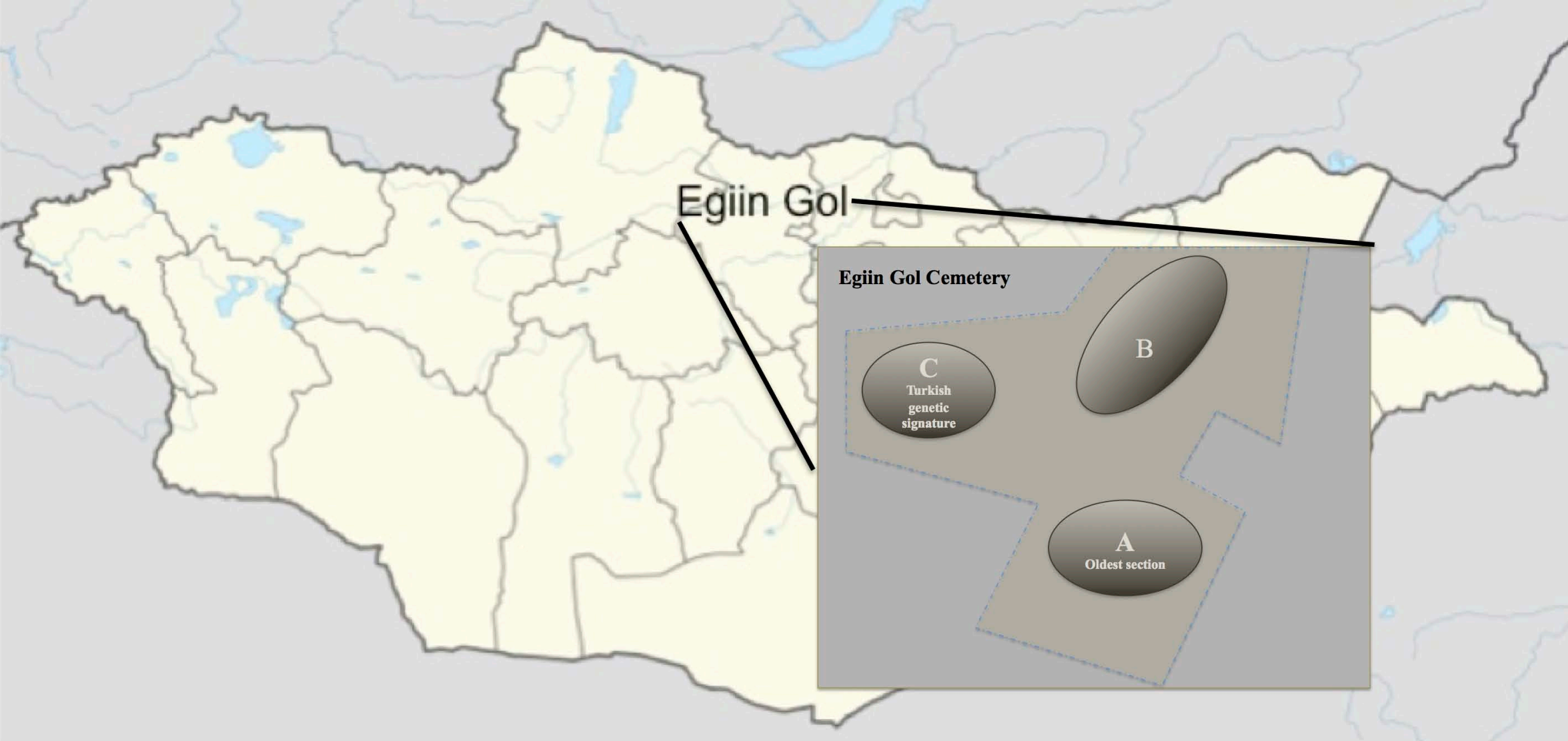


Table 1. Sample names, sample size for male and female crania, time period, institution where dat

\begin{tabular}{|c|c|c|c|c|}
\hline \multirow{2}{*}{ Region } & \multirow{2}{*}{ Sample Name } & \multicolumn{2}{|c|}{ Sample Size } & \multirow{2}{*}{ Period } \\
\hline & & Male & Female & \\
\hline \multirow[t]{6}{*}{ Mongolia } & $\begin{array}{l}\text { Chandman (Mongol Bronze } \\
\text { Age) }\end{array}$ & 14 & 12 & $700-400 \mathrm{BC}$ \\
\hline & Pooled Mongol Modern & 20 & 18 & Modern (1900 AD) \\
\hline & Pooled Mongol Period & 15 & 13 & $1100-1500 \mathrm{AD}$ \\
\hline & Mongol Turk Period & 5 & 3 & $700-800 \mathrm{AD}$ \\
\hline & Pooled Xiongnu Period & 23 & 10 & $209 \mathrm{BC}-93 \mathrm{AD}$ \\
\hline & Egiin Gol Xiongnu & 11 & 8 & $209 \mathrm{BC}-93 \mathrm{AD}$ \\
\hline \multirow[t]{3}{*}{ Japan } & Ainu & 46 & 24 & Modern (1900 AD) \\
\hline & Japan & 6 & 4 & Modern (1900 AD) \\
\hline & Jomon & 22 & 12 & $14000-300 \mathrm{BC}$ \\
\hline \multirow[t]{11}{*}{ China } & Inner Mongolia Bronze Age & 14 & 8 & $1600-1046 \mathrm{BC}$ \\
\hline & Inner Mongolia Eastern Han & 10 & 5 & 25-220 AD \\
\hline & Inner Mongolia Eastern Zhou & 8 & 7 & 771-221 BC \\
\hline & Inner Mongolia Warring States & 20 & 24 & $475-221 \mathrm{BC}$ \\
\hline & Inner Mongolia Yuan & 7 & 7 & 1271-1368 AD \\
\hline & Liaoning (Xianbei) & 17 & 15 & $300-400 \mathrm{AD}$ \\
\hline & Qinghai & 40 & 27 & 206 BC-316AD \\
\hline & South China & 23 & 5 & Modern (1900 AD) \\
\hline & Xinjiang Bronze & 10 & 11 & $2000-1500 \mathrm{BC}$ \\
\hline & Xinjiang Han & 30 & 26 & $206 \mathrm{BC}-8 \mathrm{AD}$ \\
\hline & Xinjiang Iron & 9 & 4 & $300 \mathrm{BC}$ \\
\hline \multirow[t]{14}{*}{ Siberia } & Buryat & 9 & 10 & Modern (1900 AD) \\
\hline & Chuckchi & 3 & 3 & Modern (1900 AD) \\
\hline & Evenks & 7 & 10 & Modern (1900 AD) \\
\hline & Iron Age Siberia & 18 & 12 & $700-200 \mathrm{BC}$ \\
\hline & Iron Age Tuva & 8 & 11 & $700-200 \mathrm{BC}$ \\
\hline & Kalmyk & 14 & 19 & Modern (1900 AD) \\
\hline & Orochi & 8 & 9 & Modern (1900 AD) \\
\hline & Pazyryk & 27 & 19 & $600-300 \mathrm{BC}$ \\
\hline & Siberia Bronze Age & 6 & 4 & $4500-700 \mathrm{BC}$ \\
\hline & Tagar & 9 & 9 & $700-300 \mathrm{BC}$ \\
\hline & Tuva & 16 & 20 & Modern (1900 AD) \\
\hline & Ulchi & 5 & 10 & Modern (1900 AD) \\
\hline & Siberia Medieval & 27 & 20 & $1100-1500 \mathrm{AD}$ \\
\hline & Yakut & 14 & 17 & Modern (1900 AD) \\
\hline
\end{tabular}


Table 2. Definition of craniofacial li

Landmark

Nasion

Ectoconchion

Zygoorbitale

Zygomaxillare

Prosthion

Bregma

Piriform Aperture (Left)

Piriform Aperture (Right)

Superior Terminate at

Nasomaxillary Suture (Left)

Superior Terminate at

Nasomaxillary Suture (Right)

Alare (Left)

Alare (Right)

Frontomalare Temporale (Left)

Frontomalare Posterior (Left)

Frontomalare Temporale (Right)

Frontomalare Posterior (Right)

Orbitale (Left)

Orbitale (Right)

Glabella

Basion

Opisthocranion

Lambda

Inion

Opisthion 
Table 3. Partial Mantel tests using 50 samples. Morphological distance (BIO) is the squared Mahalanobis distance between populations, geographic distance is great circle distances in kilometers (GEO), and temporal distance is based on median dates for time periods.

\begin{tabular}{ccc} 
Global Series & Partial & $\mathrm{r}$ \\
\hline BIO x GEO & Temporal & $0.33819(0.00060)^{*}$ \\
BIO x TEMP & Spatial (GEO) & $0.12618(0.13889)$ \\
\hline * significance calculated after 10,000 permutations in a two-tail test $(\alpha=0.05)$ distribution.
\end{tabular}

* significance calculated after 10,000 permutations in a two-tail test $(\alpha=0.05)$ distribution. 
Table 4. Relethford-Blangero results for Mongolian and Central Asian sample comparison. Within-Group Phenotypic Variance

\begin{tabular}{|c|c|c|c|c|c|}
\hline Population & $\mathrm{r}_{\mathrm{ii}}$ & Observed & Expected & Residual & SE \\
\hline Kazakh & 0.097 & 0.793 & 1.251 & -0.458 & 0.022 \\
\hline Pooled Xiongnu Period & 0.099 & 0.860 & 1.249 & -0.389 & 0.012 \\
\hline Uighur & 0.144 & 0.820 & 1.186 & -0.366 & 0.023 \\
\hline Uzbek & 0.154 & 0.923 & 1.173 & -0.250 & 0.023 \\
\hline Pooled Mongol Period & 0.155 & 0.913 & 1.172 & -0.259 & 0.016 \\
\hline Pooled Mongol Modern & 0.160 & 0.848 & 1.165 & -0.316 & 0.014 \\
\hline Turkmen & 0.226 & 0.856 & 1.072 & -0.216 & 0.025 \\
\hline Kyrgyz & 0.232 & 0.811 & 1.064 & -0.253 & 0.020 \\
\hline Chuvash & 0.403 & 0.657 & 0.828 & -0.171 & 0.033 \\
\hline Egiin Gol Xiongnu & 0.473 & 0.894 & 0.730 & 0.164 & 0.034 \\
\hline Chandman & 0.559 & 1.312 & 0.611 & 0.701 & 0.031 \\
\hline Mongol Turk Period & 0.622 & 0.861 & 0.523 & 0.338 & 0.061 \\
\hline India & 1.467 & 0.828 & -0.648 & 1.476 & 0.074 \\
\hline
\end{tabular}

Unbiased $\mathrm{F}_{\mathrm{ST}}=0.37$ 
Table 5. Relethford-Blangero results for Mongolian and Chinese sample comparison.

\begin{tabular}{|c|c|c|c|c|c|}
\hline \multirow[b]{2}{*}{ Population } & \multirow[b]{2}{*}{$\mathrm{r}_{\mathrm{ii}}$} & \multicolumn{3}{|c|}{ Within-Group Phenotypic Variance } & \multirow[b]{2}{*}{ SE } \\
\hline & & Observed & Expected & Residual & \\
\hline Liaoning & 0.070 & 1.021 & 1.241 & -0.220 & 0.011 \\
\hline Inner Mongolia Eastern Han & 0.101 & 0.821 & 1.199 & -0.378 & 0.020 \\
\hline Xinjiang Bronze & 0.134 & 0.676 & 1.156 & -0.479 & 0.018 \\
\hline Xinjiang Iron & 0.161 & 0.650 & 1.119 & -0.469 & 0.025 \\
\hline Qinghai & 0.168 & 0.736 & 1.110 & -0.374 & 0.011 \\
\hline Pooled Xiongnu Period & 0.176 & 0.981 & 1.100 & -0.119 & 0.016 \\
\hline Inner Mongolia Bronze Age & 0.185 & 0.963 & 1.087 & -0.124 & 0.020 \\
\hline Pooled Mongol Modern & 0.190 & 0.954 & 1.081 & -0.127 & 0.015 \\
\hline Inner Mongolia Warring States & 0.190 & 0.705 & 1.080 & -0.375 & 0.014 \\
\hline Xinjiang Han & 0.216 & 0.730 & 1.046 & -0.317 & 0.013 \\
\hline Pooled Mongol Period & 0.235 & 1.026 & 1.021 & 0.005 & 0.020 \\
\hline Inner Mongolia Yuan & 0.261 & 0.726 & 0.986 & -0.260 & 0.029 \\
\hline Inner Mongolia Eastern Zhou & 0.262 & 0.988 & 0.985 & 0.003 & 0.030 \\
\hline Egiin Gol Xiongnu & 0.675 & 0.990 & 0.434 & 0.556 & 0.040 \\
\hline South China & 0.785 & 0.909 & 0.287 & 0.622 & 0.035 \\
\hline Mongol Turk Period & 0.861 & 0.911 & 0.185 & 0.726 & 0.071 \\
\hline Chandman & 0.915 & 1.442 & 0.113 & 1.329 & 0.039 \\
\hline
\end{tabular}

Unbiased $\mathrm{F}_{\mathrm{ST}}=0.32$ 
Table 6. Relethford-Blangero results for Mongolian and Siberian sample comparison.

\begin{tabular}{lccccc} 
& & \multicolumn{2}{c}{ Within-Group Phenotypic Variance } & \\
\cline { 3 - 5 } Population & $\mathrm{r}_{\mathrm{ii}}$ & Observed & Expected & Residual & SE \\
\hline Iron Age Tuva & 0.060 & 0.810 & 1.266 & -0.457 & 0.014 \\
Siberia Medieval & 0.086 & 0.767 & 1.231 & -0.464 & 0.009 \\
Pazyryk & 0.109 & 0.761 & 1.200 & -0.439 & 0.010 \\
Pooled Xiongnu Period & 0.117 & 0.979 & 1.189 & -0.210 & 0.013 \\
Tuva & 0.127 & 0.848 & 1.175 & -0.327 & 0.013 \\
Iron Age Siberia & 0.130 & 0.802 & 1.172 & -0.370 & 0.014 \\
Pooled Mongol Modern & 0.142 & 0.925 & 1.156 & -0.230 & 0.013 \\
Kalmyk & 0.147 & 0.746 & 1.149 & -0.403 & 0.014 \\
Pooled Mongol Period & 0.163 & 1.055 & 1.128 & -0.073 & 0.017 \\
Tagar & 0.183 & 0.745 & 1.100 & -0.355 & 0.022 \\
Yakut & 0.197 & 1.027 & 1.081 & -0.055 & 0.017 \\
Orochi & 0.226 & 0.857 & 1.043 & -0.186 & 0.025 \\
Buryat & 0.254 & 0.769 & 1.004 & -0.235 & 0.025 \\
Siberia Bronze Age & 0.274 & 0.807 & 0.978 & -0.171 & 0.037 \\
Ulchi & 0.280 & 0.851 & 0.970 & -0.119 & 0.030 \\
Evenks & 0.384 & 0.654 & 0.830 & -0.176 & 0.032 \\
Egiin Gol Xiongnu & 0.822 & 1.014 & 0.239 & 0.774 & 0.043 \\
Mongol Turk Period & 0.953 & 0.959 & 0.064 & 0.895 & 0.073 \\
Chandman & 0.965 & 1.444 & 0.047 & 1.397 & 0.040 \\
Chuckchi & 1.180 & 0.960 & -0.243 & 1.202 & 0.094 \\
\hline Unbiased F & & & & & \\
\hline
\end{tabular}

Unbiased $\mathrm{F}_{\mathrm{ST}}=0.34$ 